\title{
EFFICIENCY OF TRAINING UNMANNED AERIAL VEHICLES PERSONNEL
}

\section{EFEKTYWNOŚĆ SZKOLENIA PERSONELU BEZZAŁOGOWYCH STATKÓW POWIETRZNYCH}

\author{
Wladysław Melnarowicz
}

Air Force Institute of Technology. Instytut Techniczny Wojsk Lotniczych

\begin{abstract}
An important field in the process of unmanned aerial vehicles (UAV) operation is the system of training operators and technicians. The article presents methods for measuring and evaluating the effectiveness of training systems and their suitability for use in assessing the effectiveness of training of unmanned aircraft personnel. Based on the results of the research carried out in the actual training system, a model for adapting the program and organizing training of airline personnel to measure and evaluate training outcomes was developed.
\end{abstract}

Keywords: training, training effectiveness, modular program, unmanned aerial vehicle $(U A V)$.

Streszczenie: Ważnym obszarem w procesie eksploatacji bezzałogowych statków powietrznych (BSP) jest system szkolenia operatorów i techników. W niniejszej publikacji zaprezentowane zostaty metody pomiaru, oceny efektywności systemów szkoleniowych oraz ich przydatność do stosowania $w$ ocenie efektywności szkolenia personelu bezzałogowych statków powietrznych. Na podstawie wyników badań realizowanych $w$ rzeczywistym systemie szkolenia, opracowano model dostosowania programu i organizacji szkolenia personelu BSP do pomiaru i oceny efektów szkoleniowych.

Stowa kluczowe: szkolenie, efektywność szkolenia, program modułowy, bezzatogowy statek powietrzny (BSP). 
Efficiency of training unmanned aerial vehicles personnel

Efektywność szkolenia personelu bezzałogowych statków powietrznych

\section{Wstęp}

We wszelkich procesach związanych $\mathrm{z}$ tworzeniem innowacyjnych rozwiązań technicznych ich użytkowaniem i obsługą, potrzebny jest transfer wiedzy. Wiąże się on z przekazem informacji, argumentów, przykładów, treści od osób, które je zdobyły (np. poprzez doświadczenie czy naukę) tym wszystkim, którzy tworzą i eksploatują systemy powietrzne. Tu pojawia się miejsce na proces przekazywania wiedzy i umiejętności zwany szkoleniem. Jak zbadać i ocenić czy system szkolenia personelu bezzałogowych statków powietrznych (BSP) jest efektywny? Autor opracowania próbuje odpowiedzieć na to pytanie poprzez określenie metod i narzędzi pomiaru i oceny efektywności oraz przedstawienie strategii konstruowania programu nauczania która ten pomiar umożliwi.

Podstawowa strategia konstruowania systemu szkolenia obejmuje następujące cztery fazy:

- Analizowanie wymagań systemu;

- konstruowanie systemu szkolenia;

- ocena efektywności szkolenia;

- zaplanowanie sprzężenia zwrotnego.

Pierwsze dwie fazy konstruowania systemu szkolenia personelu bezzałogowych statków powietrznych (BSP), szczegółowo opisano w monografii naukowej „Bezzałogowe statki powietrzne - zastosowanie, przepisy normujące użytkowanie, system szkolenia", Melnarowicz W i K, ITWL, Warszawa 2017 r.

Artykuł zawiera metodykę konstruowania trzeciej i czwartej fazy systemu szkolenia, która umożliwia pomiar i obiektywną ocenę efektywności szkolenia oraz zaplanowanie sprzężenia zwrotnego zapewniając w ten sposób nieustanną korektę nieefektywnych elementów systemu i interakcji systemowych, po to aby osiągnąc jak największą skuteczność szkolenia operatorów i techników bezzałogowych statków powietrznych.

\section{Pojęcie i mierniki efektywności}

Efektywność jest terminem złożonym mającym wiele synonimów, lecz z uwagi na jej wielowymiarowość, trudno jest ją jednoznacznie definiować. Wielu ekonomistów i inżynierów twierdzi, że jest to miara sprawności i skuteczności w osiąganiu zamierzonych celów. Wyróżnia się dwa podstawowe podejścia do efektywności :

- celowościowe ( prakseologiczne),

- systemowe.

Ujęcie celowościowe prezentują między innymi: T. Kotarbiński, T. Pszczółkowski, J. Zieleniecki i inni. Zakłada ono, że organizację tworzy się po to by realizowała cele. W tym kontekście pojęcie efektywności utożsamiane jest $\mathrm{z}$ pojęciem sprawności, której elementami są: skuteczność, korzystność i ekonomiczność. 
Podejście systemowe z kolei zakłada, że ocenie poddawana jest cała organizacja, a stopień realizacji celów jest tylko jednym z elementów oceny efektywności. W tym ujęciu ocena efektywności organizacji powinna spełniać trzy zasadnicze funkcje: decyzyjną, argumentacyjną i informacyjną. Inne ujęcie efektywności podaje E. Skrzypek [2009]. która wyodrębnia cztery miary efektywności:

- dynamiczny,

- finansowy,

- rynkowy,

- operacyjny.

Wszystkie te rodzaje efektywności stanowią szczególne przypadki efektywności w ujęciu ekonomicznym potwierdzają to wskazane przez autorkę narzędzia pomiaru.

Encyklopedia PWN definiuje efektywność ekonomiczną jako rezultat działalności gospodarczej określony przez relację uzyskanego efektu do nakładu. Efektywność w sensie ekonomicznym można wyrazić w sposób dwojaki:

- różnicowy jako $\mathrm{E}=\mathrm{W}-\mathrm{N}$ (Wynik - Nakład),

- ilorazowy jako $E=\frac{W}{N}$.

Działanie uznaje się jako efektywne jeżeli wskaźnik E jest większy od 1 (E > 1), czyli osiągnięte efekty są większe od zainwestowanych nakładów.

Bardzo często w ujęciu ekonomicznym i nie tylko, skuteczność i efektywność traktowane są jako pojęcia niezależne, które w zależności od sytuacji mogą być jedną z czterech możliwości działania zaprezentowanych na rys.1.

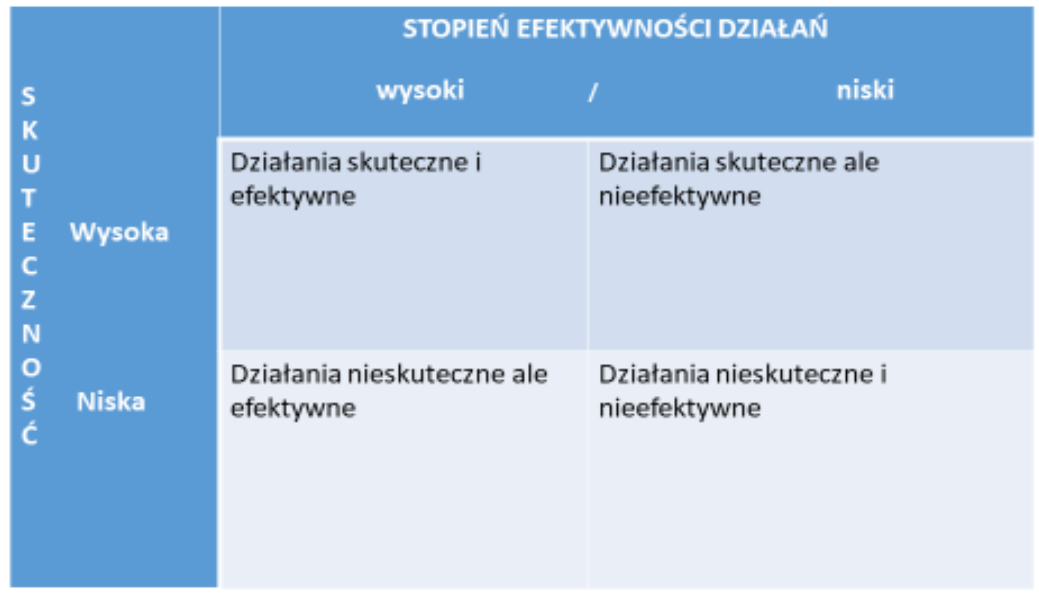

Rys.1 Skuteczność i efektywność w ujęciu ekonomicznym

Skuteczne jest takie działanie, które prowadzi do zamierzonych celów. Ale należy pamiętać o tym, że nie każde działanie skuteczne ma swoje odzwierciedlenie w działaniu efektywnym. Efektywność firmy zależy od wielkości nakładów i można zwiększać efektywność poprzez minimalizację nakładów lub maksymalizowanie efektów (rys. 2). 


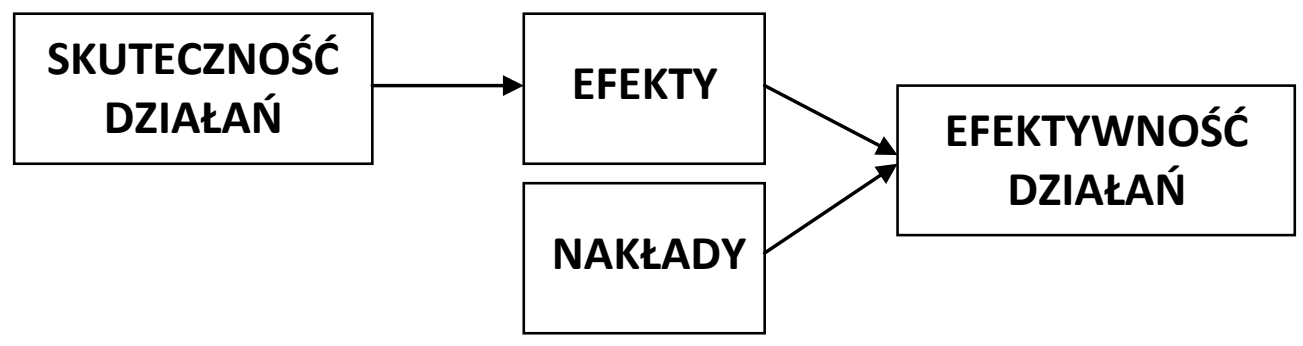

\section{Rys. 2 Zależność między skutecznością i efektywnościa}

Na efektywność ekonomiczną w dużej mierze wpływa zarządzanie przez jakość, które zakłada ciągłe doskonalenie i poprawę wszystkich aspektów funkcjonowania firmy szkoleniowej. Zestawienie definicji efektywności lotniczych systemów technicznych $\mathrm{w}$ sensie opisowym i normatywnym przedstawia prof. Jerzy Lewitowicz [2006]. Efektywność w ujęciu opisowym stanowi łączną cechę systemu i procesu jego eksploatacji uwidocznioną poprzez skutki zastosowania systemu, a definicja normatywna efektywności brzmi: „Efektywność wyraża stopień realizacji zadań eksploatacyjnych i nakładów na ich wykonanie mających miejsce w określonych warunkach eksploatacji i określonym przedziale czasu". Na tak rozumianą efektywność mają wpływ następujące czynniki:

- skutki działania w aspekcie stawianych celów,

- ponoszone nakłady na realizację celu głównego,

- miary ocenowe, warunki działania systemu i czas,

- zdolność potencjalna systemu określająca jego zdatność do realizacji zadań w poszczególnych stanach eksploatacyjnych,

- nakłady na użytkowanie technicznych środków dla utrzymania zdatności technicznej,

- zdolność działania w różnych warunkach, w tym z lotnisk zapasowych,

- podatność eksploatacyjna, w tym podatność na odnowę profilaktyczną i poawaryjną,

- zachowawczość systemu i sposób realizacji procesu eksploatacyjnego.

Natomiast w działaniach eksploatacyjnych autor rozróżnia dwa rodzaje efektywności:

- Efektywność eksploatacyjną - jako efekt związany z przejściem statku powietrznego przez różne stany eksploatacyjne.

- Efektywność operacyjną - jako efekt realizowania zadań eksploatacyjnych.

Czytelny system całościowej oceny efektywności proponuje K. Lisiecka, która określiła przykładowe mierniki efektywności organizacyjnej i ekonomicznej dla trzech poziomów:

- efektywnej organizacji,

- efektywnego procesu,

- efektywnego stanowiska pracy. 
Na tej podstawie K. Lisiecka [2002] określiła czytelne mierniki efektywności organizacyjnej i ekonomicznej dla wyżej wymienionych poziomów, co przedstawia rys.3.

\begin{tabular}{|c|c|c|c|}
\hline \multirow{2}{*}{$\begin{array}{l}\text { Mierniki } \\
\text { poziomów } \\
\text { efektywności }\end{array}$} & \multicolumn{3}{|c|}{ Poziom efektywności } \\
\hline & Organizacji & Procesów & Stanowiska pracy \\
\hline Organizacyjnej & $\begin{array}{l}\text { - Ilość produktów, } \\
\text { - udział w rynku, } \\
\text { - udział w reklamacji, } \\
\text { - udział zwrotów. }\end{array}$ & $\begin{array}{l}\text { - zakupy internetowe, } \\
\text { udział procesów } \\
\text { uregulowanych. }\end{array}$ & $\begin{array}{l}\text { - udział strat, } \\
\text { - udział braków, } \\
\text { - udział odpadów. }\end{array}$ \\
\hline Ekonomicznej & $\begin{array}{l}\text { - } \text { rentowność, } \\
\text { coshnność finansowa } \\
\text { - wskaźnik rotacji } \\
\text { należności }\end{array}$ & $\begin{array}{l}\text { Wydajność } \\
\text { (zysk/jednostkę) }\end{array}$ & $\begin{array}{l}\text { - wydajność pracy, } \\
\text { - obniżka kosztów }\end{array}$ \\
\hline
\end{tabular}

Rys. 3 Mierniki pomiaru efektywności

W literaturze przedmiotu prezentowane są różne metody pomiaru efektywności, uwzględniające różne wymiary i wynikające z nich kryteria. Analiza konkretnego rodzaju działalności i określenie celów i zadań stanowi istotny punkt odniesienia w tworzeniu miar i oceny efektywności. Kompleksowy pomiar i ocena efektywności procesu szkolenia jest bardzo skomplikowana, zwłaszcza w kontekście faktu, że powinna znaleźć odzwierciedlenie w całym specyficznym systemie jakim bez wątpienia jest system szkolenia.

\section{Pomiar i ewaluacja szkoleń}

Dobrze przeprowadzone szkolenie w założeniu ma wywierać wpływ na uczestników i powodować progres (korzystną zmianę, przyrost świadomości, umiejętności i wreszcie kompetencji). Zmiana ta może dotyczyć stanu posiadanej wiedzy, zmiany zachowań czy postaw, lub innych elementów będących konsekwencją przekazanych treści. Sprawdzenie, jak duże różnice można zaobserwować między stanem początkowym uczestnika szkolenia i jego stanem końcowym (po zakończeniu programu edukacyjnego), może umożliwić rzetelna ewaluacja szkoleń. Ocena efektywności szkolenia jest koniecznym składnikiem systematycznego modelu szkolenia [Janiak, 2001]. Pojęcie to można zdefiniować jako systemowe gromadzenie informacji i formułowanie sądu wartościującego wszystkich elementach systemu szkolenia. Badania dowodzą, że większość instytucji szkoleniowych i zlecających szkolenie koncentruje się przede wszystkim na dwóch pierwszych etapach szkolenia: jego przygotowaniu i przeprowadzeniu. 
Efficiency of training unmanned aerial vehicles personnel

Efektywność szkolenia personelu bezzałogowych statków powietrznych

Jednocześnie zaznacza się tendencja do minimalizowania lub całkowitego pomijania drugiej fazy badania, czyli pomiaru poziomu zachowań absolwentów i wymiernych korzyści ze szkolenia dla firmy.

Tak sformułowana ocena precyzuje, że o efektywności można mówić wtedy, gdy jest ona mierzona i analizowana na każdym etapie prowadzenia szkolenia i po jego zakończeniu

Nie jest to więc działanie tylko o charakterze ex post. Badanie efektywności szkoleń jest procesem ciągłym. Nie można go sprowadzać jedynie do wyznaczania wskaźników ekonomicznych, a uzyskane efekty przeliczać wyłącznie na zyski, ponieważ efekty szkoleń mogą mieć również postać niematerialną, jeżeli wynika to z celów szkolenia. Oczywiście na efektywność szkoleń składa się bardzo wiele czynników. Część z najważniejszych determinantów efektywności szkoleń wynika $\mathrm{z}$ procesu przygotowawczego. Naturalnie sam przebieg szkolenia ma ogromne znaczenie i wpływ na efektywność, proces poszkoleniowy zawiera również istotne elementy, które przekładają się na efektywność całego procesu. Przyjąć również należy istotne kryteria dotyczące płaszczyzny oceny efektywności szkoleń, w zależności od przyjętych założeń, dotyczących analizy struktury korzyści. Można dojść do wniosku, że niekiedy szkolenia mogą być nieefektywne z punktu widzenia organizacji, a są bardzo korzystne i efektywne z punktu widzenia celów i motywów uczestnika szkolenia.

Pomiaru i ewaluacji szkoleń dotyczą regulacje Unii Europejskiej i prace wielu badaczy systemów szkolenia i ekspertów zajmujących się systemami zarządzania. Spośród wielu definicji ewaluacji opisanych w literaturze przedmiotu badań na zastosowanie w systemach szkolenia zasługują dwie definicje:

- Ewaluacja to ocena wartości interwencji $\mathrm{z}$ zastosowaniem określonych kryteriów tejże oceny, podejmowana w celu określenia efektywności interwencji, oszacowania w odniesieniu do celów, a także analizy wpływu na specyficzne problemy strukturalne [Rozporządzenie Rady Unii Europejskiej z dn. 21.06.1999 r.].

- Ewaluacja to systematyczne badanie zdarzeń, które mają miejsce w ramach aktualnie realizowanego programu, bądź stanowią jego konsekwencję - badania te mają przyczynić się do usprawnienia zarówno tego programu, jak i innych, stawiających te same cele ogólne [Cronbach, 1980].

Powyższe definicje ukazują, że proces ewaluacji może odnosić się do różnych elementów w zależności od przyjętych kryteriów.

Każde działanie podlega okresowej ewaluacji według wcześniej określonych wymiernych kryteriów. W opracowaniu i implementacji szkolenia operatorów BSP przyjąłem następujące kryteria ewaluacyjne:

- trafność rozwiązań - kryterium, które ma na celu porównanie celów $\mathrm{z}$ istniejącymi rozwiązaniami szkoleniowymi,

- skuteczność - to stopień osiągnięcia założonych celów, sprawdzenie czy istnieje obiektywny system oceny przydatności zawodowej absolwentów umożliwiający porównanie przydatności prognozowanej do rzeczywistego powodzenia absolwentów na stanowiskach pracy, 
- efektywność - kryterium to pozwala ocenić „poziom ekonomiczności” czyli stosunek nakładów do uzyskanych efektów i rezultatów,

- trwałość efektów - kryterium to pozwala ocenić czy proces szkolenia jest realizowany na stałym założonym poziomie w dłuższym okresie czasu,

- użyteczność i spójność - to kryterium, które pozwala ocenić czy realizacja celów jest dostosowana do zasobów ludzkich, struktury organizacyjnej, środków technicznych i finansowych oraz obowiązujących przepisów i norm. Ocenia również spójność zewnętrzną z krajowym systemem edukacyjnym i szkolnictwem zawodowym innych krajów .

Ewaluację modułowych programów szkolenia należy przeprowadzić:

- po opracowaniu projektu programu,

- w trakcie realizacji,

- po zebraniu opinii od przełożonych i absolwentów.

Każde wyżej wymienione ujęcie zgodnie zaznacza, iż istotą ewaluacji jest ocena, która ma służyć poprawie jakości szkolenia $\mathrm{w}$ badanym podmiocie.

Ewaluacja jest procesem złożonym, w którym możemy wyróżnić trzy nw. różne możliwe działania (wg dokumentów zatwierdzonych przez Unię Europejską).

\section{Ewaluację wstępną (ex ante).}

Celem ewaluacji ex ante jest zagwarantowanie, że środki przeznaczone na realizację projektu szkoleniowego zostaną wykorzystane w sposób umożliwiający osiągnięcie najlepszych rezultatów. Możliwe działania to:

- ocena pod względem merytorycznym i realizacyjnym wstępnej wersji projektu,

- analiza SWOT danego obszaru i dokonanie na jej podstawie oceny proponowanych działań szkoleniowych,

- określenie przewidywanych długoterminowych skutków projektu szkoleniowego.

\section{Ewaluację dokonywaną w trakcie realizacji projektu (on going).}

Celem ewaluacji on going, zwanej też okresową (mid term), jest dostarczenie informacji na temat skuteczności osiągania celów i efektywności poszczególnych szkoleń (porównanie wyników $\mathrm{z}$ nakładami) oraz oszacowanie wstępnych rezultatów interwencji, jej adekwatności w stosunku do problemu oraz stopnia osiągnięcia zakładanych celów. Możliwe konsekwencje to:

- wcześniejsze zakończenie projektu szkoleniowego,

- przeformułowanie celów projektu szkoleniowego.

\section{Ewaluację końcową (ex post).}

Głównym celem ewaluacji ex post jest dostarczenie informacji na temat długotrwałych efektów działań rozwojowych. Ewaluacja ex post nie ma wpływu na dalszy przebieg projektu, ale może wygenerować kolejny, nowy projekt. Służy zebraniu doświadczeń i wyciągnięciu wniosków na przyszłość. 
Efficiency of training unmanned aerial vehicles personnel

Efektywność szkolenia personelu bezzałogowych statków powietrznych

\section{Założenia konstrukcji efektywnego modelu szkolenia personelu BSP}

Jak zbudować od podstaw efektywny model szkolenia personelu bezzałogowych statków powietrznych?

Przygotowanie specjalistyczne kadr oraz wielkość nakładów finansowych stanowią podstawowy wyznacznik sprawności systemu szkolenia. Konsekwencją tej nowej sytuacji jest intensyfikacja działań zmierzających do zwiększenia efektywności szkolnictwa zawodowego, a w szczególności zakresie praktycznego szkolenia zgodnie ze standardami NATO i Unii Europejskiej. Standardy szkolenia w lotnictwie europejskich krajów NATO oparte są o Europejskie Ramy Kwalifikacji (EQF), opisane przez Europejską Agencję Bezpieczeństwa Lotnictwa, jako kwalifikacje obsługi technicznej statków powietrznych (EASA Part-66), kwalifikacje do licencji pilota turystycznego (EASA PPL(A)) i Standard NATO ATP- 3.3.7 (STANAG 4670) „Guidance for the training of unmanned aircraft systems operators".

Programy szkolenia zawodowego oparte na standardach EQF mają konstrukcję modułową, uwzględniają przygotowanie ogólnozawodowe kandydatów i specyfikę specjalności w lotnictwie wojskowym.

Zasadniczym celem doskonalenia systemu szkolenia zawodowego personelu lotniczego jest weryfikacja i modernizacja podstaw programowych oraz organizacyjnych pod katem zwiększenia efektywności szkolenia i poprawy poziomu praktycznych umiejętności absolwentów. Badania przeprowadzone przez autora niniejszego opracowania dowodzą, że połączenie nauczania teorii z praktyką przynosi duże korzyści zarówno w przyswajaniu i zapamiętywaniu wiedzy, jak również nauczaniu umiejętności.

Człowiek po godzinie zapomina około $56 \%$ przestudiowanego materiału, a po jednym dniu pozostaje zaledwie 33\% zdobytej wiedzy. Dlatego powtórkę, bądź nauczanie praktyczne, należy realizować niezwłocznie po zrealizowaniu treści teoretycznych. To utrzymuje poziom wiedzy i przyspiesza kształtowanie umiejętności. W ten sposób wiedza zostaje dołączona do tzw. pamięci trwałej, a wykonywanie ćwiczeń utrwala, porządkuje i systematyzuje treści oraz zwiększa efektywność nauczania i uczenia się. Skuteczność zapamiętywania wiedzy użytecznej, po wprowadzeniu działania (ćwiczeń) bezpośrednio po zrealizowaniu teoretycznych podstaw nauczania, sięga 70\% - 90\%. To przemawia jednoznacznie za wprowadzaniem do szkolenia modułowych programów nauczania, w których nauczanie wiedzy i umiejętności zawarte jest w modułach i jednostkach modułowych i jest realizowane jednocześnie (rys.4).

Nie można usprawniać systemu szkolenia oszczędnościowo, zmieniając jedynie program, a pozostawiając bez zmian strukturę i organizację szkolenia. 


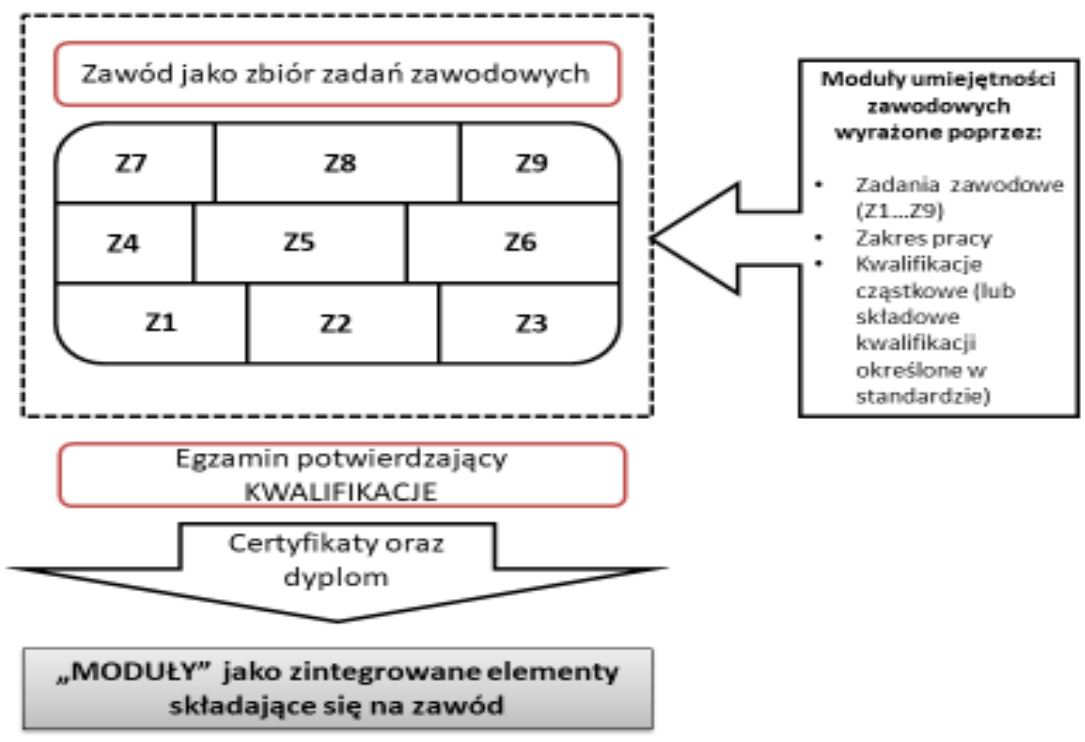

Rys. 4 Moduly umiejętności zawodowych

\section{Dostosowanie programu nauczania do pomiaru i oceny szkolenia}

Wymierna ocena efektywności wymaga starannego zaprogramowania systemu szkolenia i wyboru odpowiednich kryteriów oceny. W tym celu konieczna jest odpowiednia konstrukcja programu nauczania zawierająca operacyjne cele szkolenia. Ocena efektywności szkolenia jest ułatwiona, jeżeli program nauczania jest opracowany w technologii MES (Module of Employable Skills). Programy takie noszą nazwę programów modułowych, w których specyfika czynności wykonywanych $\mathrm{w}$ ramach pracy wyrażana jest $\mathrm{w}$ programie nauczania $\mathrm{w}$ postaci modułów i jednostek modułowych.

Modułowy program kształcenia lub szkolenia zawodowego, to zestaw celowo dobranych, modułów kształcenia zawodowego (M) i odpowiadających im jednostek modułowych (JM), wyznaczających treść zajęć edukacyjnych, które umożliwiają ukształtowanie wiedzy i umiejętności oraz cech psychofizycznych właściwych dla danego zawodu (rys. 5).

W kształceniu zawodowym „moduły" stanowią pochodną funkcji i zadań zawodowych realizowanych na stanowiskach pracy. W koncepcji kształcenia opartej na idei „modularyzacji” przyjmuje się założenie, że podstawą zdobywania wiedzy, umiejętności i kształtowania postaw zawodowych jest wykonywanie różnorodnych czynności i operacji w sytuacjach rzeczywistych bądź symulowanych. 
Efficiency of training unmanned aerial vehicles personnel Efektywność szkolenia personelu bezzałogowych statków powietrznych

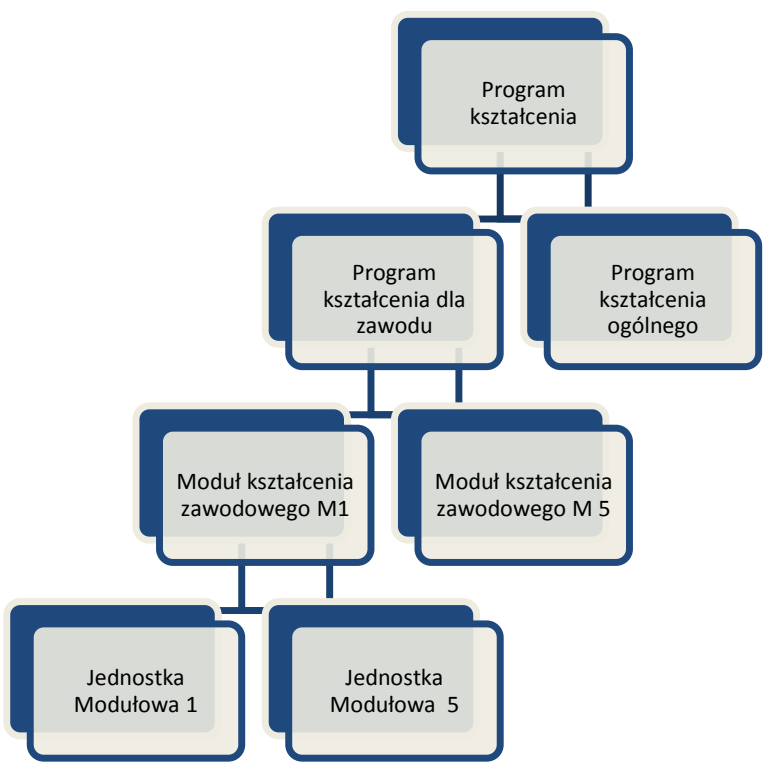

Rys. 5 Struktura modutowego programu nauczania,

Najważniejszym etapem w konstrukcji modułów jest wprowadzanie operacyjnych celów kształcenia, ponieważ to cel operacyjny opisuje zachowanie jakiego oczekuje się od ucznia po zakończeniu kursu. Cel operacyjny obejmuje trzy składniki:

- zachowanie końcowe,

- warunki jego przejawiania,

- standardy osiągania zachowania końcowego.

Zachowanie końcowe należy opisywać przy użyciu czasowników operacyjnych to znaczy takich które opisują czynności, które można obserwować, mierzyć i oceniać poziom opanowania umiejętności. To właśnie powoduje, że możliwy staje się pomiar stopnia osiągnięcia celów dydaktycznych i prowadzenie wymiernej oceny efektywności procesu szkolenia, a także ustalenie rzeczywistego przyrostu kwalifikacji po zakończeniu szkolenia.

Integracja teorii $\mathrm{z}$ praktyką jest kluczową i najważniejszą zaletą modułowej koncepcji szkolenia zawodowego. W przeciwieństwie do kształcenia przedmiotowego, gdzie istnieje rozdział pomiędzy tymi elementami nauczania, w kształceniu i szkoleniu modułowym uczeń po zdobyciu pewnego zasobu wiedzy teoretycznej, przechodzi zaraz do ćwiczeń i ma możliwość utrwalania wiedzy w praktyce oraz umiejętności jej praktycznego zastosowania.

Modulowa konstrukcja programu szkolenia operatorów i techników bezzałogowych statków powietrznych i zawarte $w$ niej operacyjne cele szkolenia, mają kluczowe znaczenie w systemie pomiaru i ocenie efektywności szkolenia zawodowego. 


\section{Podsumowanie}

Pomiar efektywności działania jest jedną z najbardziej dynamicznie rozwijających się dziedzin ostatnich lat. Wysoka efektywność, to nie tylko skuteczna realizacja celów, ale również czynnik ekonomiczny związany z nakładami czyli kosztami. Pomiar efektywności szkolenia jest bardzo skomplikowany ponieważ dotyczy nie tylko wymiernych korzyści osiąganych przez firmę szkoleniową, ale przede wszystkim musi przynosić korzyść firmie zlecającej szkolenie pracowników. Finansowanie szkolenia, dla każdej firmy produkcyjnej czy usługowej jest kosztem który powinien się zwrócić. W interesie zarówno firmy szkoleniowej, jak również kierującej pracowników na szkolenie, jest taka konstrukcja systemu szkolenia, która umożliwi precyzyjny pomiar i wymierną ocenę efektywności, zarówno w firmie szkoleniowej, jak również w firmie zlecającej szkolenie, po jego zakończeniu. W artykule przedstawiono taki model szkolenia personelu bezzałogowych statków powietrznych, w którym zaprogramowany jest pomiar i wymierna ocena efektywności szkolenia operatorów i techników BSP. Model ten autor $\mathrm{z}$ powodzeniem stosował szkoleniu i badaniu efektywności szkolenia personelu inżynieryjno-lotniczego na różnych poziomach szkolenia i proponuje zastosowanie go w szkoleniu personelu BSP.

\section{Literatura}

[1] Bramley P., Ocena efektywności szkoleń, Oficyna Ekonomiczna, Kraków 2001.

[2] Davis R. H., Yelon L., Learning System Design, McGraw-Hill Inc., New York 1974

[3] Dudycz T. Efektywność - rozważania nad istota i pomiarem, Prace naukowe UE nr 144, Wrocław 2010.

[4] Janiak.I, Badanie efektywności szkoleń pracowniczych, Prace naukowe Akademii Ekonomicznej we Wroclawiu nr 900, 2001 r.

[5] Kirkpatrick D., Ocena efektywności szkoleń, Studio Emka, Warszawa 2001.

[6] Komisja Europejska, A Practical Guide for Preparing Proposals for Expenditure Programmes, Bruksela 2001.

[7] Lisiecka K., Kreowanie jakości-uwarunkowania, strategie, techniki, AE,

[8] Katowice 2002

[9] Lewitowicz J., Podstawy eksploatacji statków powietrznych, ITWL, Warszawa 2006.

[10] Melnarowicz W., Ocena efektywności szkolenia personelu BSP, ITWL, Warszawa 2018.

[11] Melnarowicz K . i W., Bezzałogowe statki powietrzne, ITWL, Warszawa 2017. 
Efficiency of training unmanned aerial vehicles personnel

Efektywność szkolenia personelu bezzałogowych statków powietrznych

[12] Phillips J.J., Stone R.D., 2011, Mierzenie wyników szkoleń, praktyczny przewodnik po sześciu najważniejszych wskaźnikach oceny, Oficyna Wolters Kluwer bussines, Warszawa 2000

[13] Skrzypek E., Jakość i efektywność, UMCS, Lublin 2009.

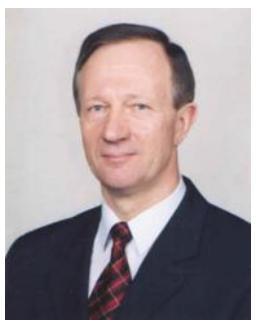

Dr inz. Wtadysław Melnarowicz, ukończyt studia na Wydziale Mechanicznym Wojskowej Akademii Technicznej $w$ specjalności: Samoloty $i$ Silniki Lotnicze. Posiada 35-letni staż dydaktyczno-naukowy. W dydaktyce zajmowat wszystkie stanowiska od wykładowcy do komendanta szkoty lotniczej. Przeprowadzit ponad 10000 godzin zajęć dydaktycznych $z$ personelem technicznym, pilotami i studentami Inżynierii Lotniczej Politechniki Wrocławskiej. Jest autorem sześciu prac badawczych, pięciu skryptów, licznych opracowań i artykułów dotyczacych szkolenia personelu lotniczego oraz współautorem czterech koncepcji systemowych wdrożonych $w$ kraju $i$ za granica. Od ośmiu lat kontynuuje dziatalność naukowo-badawcza w Instytucie Technicznym Wojsk Lotniczych oraz aktywnie uczestniczy $w$ krajowych $i$ zagranicznych konferencjach, seminariach i sympozjach o tematyce lotniczo-szkoleniowej. 